Click www.researchjournal.co.in/online/subdetail.html to purchase.

INTERNATIONAL JOURNAL OF PLANT PROTECTION

\title{
Stem application technique for sucking pest management in cotton at tribal area of Andhra Pradesh
}

\author{
E. Chandrayudu, K. Tejeswara Rao* and P. B. Pradeep Kunar
}

District Agricutral Advisory and Transfer of Technology Centre (ANGRAU), Kondempudi, Visakhapatnam (A.P.) India

\section{ARITCLE INFO}

Received : 27.07 .2020

Revised : 04.09 .2020

Accepted : 19.09 .2020

KEY WORDS :

Stem application, Cotton, Tribal farmers, Sucking pest management, Front line demonstrations (FLDs)

*Corresponding author:

Email : tejaseniorscientist@gmail.com

\begin{abstract}
Cotton is one of the most important fibre and cash crop in tribal area at Visakhapatnam district of Andhra Pradesh and plays a major share in the agricultural economy of the country. Nearly 65 per cent of cotton area is under rainfed and mainly in the plain and High altitude tribal areas of the district. Sucking pests of leaf hopper, white fly, thrips, mealy bugs, mites, redcotton bugs and aphids are becoming more serious, inviting indiscriminate use of pesticides in Bt cotton growing areas. Sucking pest incidence was controlled by the stem application of systemic insecticides viz., monocrotophos $1: 4$ ratio at 20 days after sowing and imidacloprid 200 SL with 1:20 ratio at 40 and 60 days after sowing. Within three days of application the population of sucking pests was reduced. This technique is being demonstrated and documented for two years at 20 locations in tribal farmers fields of Visakhapatnam district. Stem application in cotton showed better performance by reducing sucking pests damage of aphids $(1.89 \%)$, leaf hoppers $(3.57 \%)$, white fly $(5.86 \%)$, thrips $(4.31 \%)$, mealy bugs $(5.09 \%)$, red cotton bug $(6.82 \%)$ and mite $(8.31 \%)$ along with more number of bolls and kapas yield in demo plots when compared to the farmers practice aphids $(16.16 \%)$, leaf hoppers $(27.32 \%)$, white fly $(37.29 \%)$, thrips $(18.42 \%)$, mealy bugs $(36.87 \%)$, red cotton bug $(7.90 \%)$ and mite $(25.43 \%)$. On an average both years cotton kapas yield $(2111 \mathrm{~kg} / \mathrm{ha})$ under Front Line Demonstrations (FLDs) were higher by 19.76 per cent as compared to farmer's practices. Results from the study showed that farmers realized additional net income of Rs.17, 260 due to increased cotton kapas yield by 19.76 per cent with reduction of cost of cultivation by Rs.3300, it could be attributed in reduction of manual labour requirement for stem application and also increase in yield.
\end{abstract}

How to view point the article : Chandrayudu, E., Tejeswara Rao, K. and Pradeep Kunar, P. B. (2020). Stem application technique for sucking pest management in cotton at tribal area of Andhra Pradesh. Internat. J. Plant Protec., 13(2) : 156-159, DOI : 10.15740/HAS/IJPP/13.2/156-159, Copyright@2020: Hind Agri-Horticultural Society. 